\title{
Influence of Intellectual/Emotional/Spiritual Intelligence, Independence, and Tri Hita Karana on Auditor Performance
}

\author{
I Gusti Ayu Made Asri Dwija Putri ${ }^{1}$ \\ Ni Gusti Putu Wirawati ${ }^{2}$ \\ ${ }^{1,2}$ Faculty of Economics and Business, Udayana University, Indonesia \\ email: igamasri@yahoo.com
}

DOI: https://doi.org/10.24843/JIAB.2020.v15.i01.p08

\begin{tabular}{l}
$\begin{array}{l}\text { Jurnal Ilmiah Akuntansi } \\
\text { dan Bisnis } \\
\text { (JIAB) }\end{array}$ \\
\hline Volume 15 \\
Issue 1 \\
January 2020 \\
Page 85 - 92 \\
p-ISSN 2302-514X \\
e-ISSN 2303-1018 \\
\hline ARTICLE INFORMATION: \\
\hline Received: \\
09 July 2019 \\
Revised: \\
11 October 2019 \\
Accepted: \\
06 January 2020 \\
\hline
\end{tabular}

\section{INTRODUCTION}

Public accountants are very important for a company to help provide opinions on financial statements. Reliable and quality audit results will assist investors in making up decisions. The auditor must maintain good performance to maintain the trust of users of audited financial statements. Audit failure can occur if the auditor issues the erroneous opinion because it fails to meet the applicable requirements. An audit failure occurred in 2002 in the United States involving The Big Five Arthur Anderson who collaborated in manipulating Enron's financial statements. The company's financial statements got an unqualified opinion by Arthur Anderson Public Accounting Firm. However, the company went bankrupt after the statement was issued. The opinion could be said to be of no quality, because it was unable to predict the condition of the company in the future. The management of Enron and Arthur Andersen knew about the unprincipled practices, but in order to maintain the trust of investors and the public, both parties had fabricated financial statements starting from 1985. Andersen also violated the attitude of professionalism as an independent accountant by publishing erroneous reportsand misleading audits. Public Accounting Firms' (PAF) reputation will be at stake when the opinions given are not in accordance with the actual conditions of the company (Geiger \& Rama, 2006)

Low audit quality reflects the low quality of auditor (Novia \& Ariyanto, 2016). The term performance is often used to assess the achievement of individuals or groups. Kalbers \& Timothi (1995) states that the auditor's performance is an assessment of the work, it is conducted by supervisors, coworkers, self, and subordinates. According to Agus (2003), there are three dominant standards considering performance namely quantity, quality, and timeliness.

Possessing a good performance is not enough to be an auditor, it also requires a more comprehensive abilities consisting of intellectual, emotional, and spiritual intelligence as well as the application of Tri Hita Karana culture. Several studies related to the culture of Tri Hita Karana such as Dewi, Yuniarta\&Julianto (2017) and 
Suparsabawa \& Kustina (2018) state that Tri Hita Karana culture can affect performance. Yuliana \&Latrini (2016) shows that intellectual intelligence has a positive effect on auditor performance. Research conducted by Choiriah, (2013) found that there is a relationship between intellectual intelligence, emotional intelligence, and spiritual intelligence on auditor performance. Accountants who are only intellectually smart may not necessarily be able to provide optimal performance in conducting the audit process, but accountants who are also emotionally and spiritually smart certainly provide better performance in producing quality audit reports. Auditor performance can be seen from the ability of someone to master and manage themselves and the ability to foster relationships with others. According to Goleman, (2003) this ability is called emotional intelligence that will give effect to a person.

Research conducted by Meirnayati (2005), Choiriah (2013) and Yuliana and Latrini (2016) shows that intellectual intelligence has a very significant role in improving performance. If an auditor has high intellectual intelligence, the auditor can conduct checks well in determining or recommending audit opinions, as result better performance is achieved. If an auditor has good intellectual intelligence, then he will be able to understand and carry out their duties properly.

$\mathrm{H}_{1}$ : Intellectual intelligence has a positive effect on auditor performance.

Research conducted by Wijayanti, (2012) states that emotional intelligence will facilitate an auditor in conducting examinations, have strong motivation, self-control or emotions, empathy, and social skills that will help the auditor in tracing audit evidence and information related. An auditor who has emotional intelligence will have an empathetic attitude so that he can be more responsive to the needs of his clients and will also always motivate him to always be committed to audit quality.

$\mathrm{H}_{2}$ : Emotional intelligence has a positive effect on auditor performance.

An auditor with good spiritual intelligence is able to synergize all components of his intelligence and achieve good performance as well. Biberman and Whittey (1997) suggests the relationship between spiritual intelligence and work. Spiritual intelligence is proven to have an influence on a person's behavior at work. Research conducted by Wiersma (2002) also provides evidence about the influence of spiritual intelligence at work. It is sometimes difficult to gather information from the management, employees and other related parties. These difficulties can be overcome by the spiritual intelligence possessed by the auditor. Spiritual intelligence is shown by someone's awareness to use his experiences as a form of applying values and meanings. Through his spiritual intelligence, it is expected that an auditor can think creatively, be far-sighted, act honestly, and be free from other parties' influence in conducting the audit process.

$\mathrm{H}_{3}$ : Spiritual intelligence has a positive effect on auditor performance.

An accountant does not only need to have competency as an auditor but also independence in conducting audit. The auditor is also expected to be independent in conducting the audit. Independence is a mental attitude held by the auditor to be impartial in conducting an audit. Christiawan, (2002) states that public accountants are obliged to be honest with all interested parties who have put their trust in their work. Auditor who upholdshis independence, will not be affected and influenced by various forces originating from outside in considering the facts found in the examination (Trinaningsih, 2007). When an auditor does not have independence any longer, his working quality will be questioned by the public.

$\mathrm{H}_{4}$ : Independence influences auditor performance positively.

The quality of Public Accounting Firm (PAF) performance is largely determined by the performance of the auditor. According to Gunawan (2009) the culture of Tri Hita Karana can improve organizational performance. One way to improve one's performance in a line of work is to apply cultural values. Balinese in their social life apply a lot of values contained in Tri Hita Karana culture. Furthermore, Saputra's research (2012) states that Tri Hita Karana culture is able to strengthen the influence of the internal locus of control on the performance and satisfaction of internal auditors. Tri Hita Karana culture reflects the harmonious relationship between humans, nature and God. Some previous studies discuss the culture of Tri Hita Karana such as research done by Gunawan (2009), Pertiwi and Ludigdo (2013) state that the culture of Tri Hita Karana contains noble values that can be applied in improving performance. 
$\mathrm{H}_{5}$ : Tri Hita Karana culture has a positive effect on auditor performance.

\section{RESEARCH METHOD}

This research refers to the Theory of Attitudes and Behavior developed by Triandis, (1980), states that a person's behavior is determined by attitudes related to what people want to do, what they think they will do ( social rules), what they can do (habits) and with the consequences of the behavior they think about. The data used in this study were primary and secondary data. The population in this study were all auditors who work at the Public Accounting Firm (PAF) in Bali which are members of the Indonesian Institute of Certified Public Accountants (IICPA) in 2017.

Nonprobability sampling method with a purposive sampling technique was applied. It is the method of determining the sample with certain considerations, where sample members are chosen to make the sample represent the characteristics of the population (Sugiyono, 2016: 85). The criteria used as the basis for selecting sample members in this study were as follows: (1) auditors who work in each PAF in Bali as partners, managers, senior auditors, junior auditors and other auditor positions. Determination of this criterion was done with the consideration that although only authorized to conduct an audit, because not all auditors have the right to issue or determine the audit opinion, the results of the audit can determine the quality of the audit process; (2) Auditors who have work experience of at least 1 year. This criterion was chosen because the auditor who has at least 1-year work experience has the time and experience to adapt and assess the conditions of his work environment. A questionnaire was used to collect the data.

In this study, intellectual intelligence is proxied into three indicators, namely language ability (verbal), logical ability, and numerical ability. The establishment of a research instrument refers to indicators developed from Goleman (2003). The instrument used to measure intellectual intelligence consisted of 7 statement items. The results were then measured using a modified Likert scale, where the respondent's answer choices were rated on a 4-point scale.

Emotional intelligence is a series of someone's abilities to provide self-confidence, manage emotions when facing pressures so that he can use cognitive abilities to the full, provide motivation to himself, as well as the ability to work and interact with others.
The formation of research instruments refers to indicators developed from Goleman(2003). In this study, emotional intelligence is proxied into five indicators, namely self-introduction, self-control, motivation, empathy and social skills. The results of the answers were then measured using a modified Likert scale, where the respondent's answer choices were rated on a 4-point scale.

Spiritual intelligence is intelligence that is demonstrated through the ability of auditors to take action in accordance with the professional code of ethics, the ability to survive in life and work life and the ability to always behave honestly when carrying out duty. The establishment of a research instrument refers to indicators developed from Goleman (2003). In this study, spiritual intelligence is proxied into three indicators, namely self-integrity, respect, and unwillingness to cause unnecessary losses. The instrument used to measure spiritual intelligence consisted of 6 statement items. The results of the answers were then measured using a modified Likert scale, where the respondent's answer choices were rated on a 4-point scale.

Independence is the auditors' mental attitude to be free from the influence of other parties or not take sides in conducting audits up to the statement of opinion. Independence is proxied into three indicators, namely the duration of the relationship with the client, the independence of the execution of work, and the independence of the report. The results of the answers were then measured using a modified Likert scale, where the respondent's answer choices were scored on a 4-point scale.

The Tri Hita Karana culture is a manifestation of Balinese cultural values that contain harmony in the Balinese social life with its indicators, namely the harmony of human relations with humans, the harmony of human relations with their environment, and the harmony of human relations with God. The research instrument used to measure the culture of Tri Hita Karana was adopted from a concept developed by Windia (2007) and Suardikha (2012). The results of the answers were then measured using a modified Likert scale, where the respondent's answer choices were scored on a 4-point scale.

Auditor performance is an implementation of audit tasks that has been completed by the auditor within a certain period of time. In this study, auditor performance is proxied into three indicators, namely the quality of workers, the quantity of work, and the timeliness of report completion. The instrument used 
to measure auditor performance consisted of 9 statement items. The results of the answers were then measured using a modified Likert scale, where the respondent's answer choices were rated on a 4point scale.

Questionnaires were distributed directly to the study location and given to respondents. The questionnaire was a list of questions and written statements about the influence of intellectual intelligence, emotional intelligence, spiritual intelligence, independence, and culture of Tri Hita Karana on auditor performance. The results of the answers were then measured by a 4-point Likert scale, where the highest score is 4 and the lowest score is 1 . The criteria for determining the score for each statement item namely, respondent's answer with a score of 4 for Very Agree (VA), a score of 3 for Agree (A), score 2 for Disagree (DA) and score 1 for the Strongly Disagree (SDA).

Validity test is used to measure the validity of a questionnaire and the reliability test aims to find out the consistency of the measuring instrument used, therefore, the results obtained is the same in examining the same object and technique with different times. Before multiple linear regression analysis (multiple linear regression) is used to test existing hypotheses, the normality test, multicollinearity test and heteroscedasticity test were first performed.

Multiple linear regression analysis (multiple linear regression) is used to test the existing hypothesis, which is to see the influence of intellectual intelligence, emotional intelligence, spiritual intelligence, independence, and culture of Tri Hita Karana on the performance of auditors at public accounting firms in Bali. The analysis results are expressed in the form of multiple linear regression equations as follows.

$Y=\alpha+\beta_{1} X_{1}+\beta_{2} X_{2}+\beta_{3} X_{3}+\beta_{4} X_{4}+\beta_{5} X_{5}+$

$\varepsilon$

\section{Exlanation:}

$$
\begin{array}{ll}
\mathrm{Y} & =\text { auditor's performance } \\
\alpha & =\text { constant } \\
\beta_{1 \ldots} \beta_{5} & =\text { regression coefficient } \\
\mathrm{X}_{1} & =\text { intellectual intelligence } \\
\mathrm{X}_{2} & =\text { emotional intelligence } \\
\mathrm{X}_{3} & =\text { spiritual intelligence } \\
\mathrm{X}_{4} & =\text { independence } \\
\mathrm{X}_{5} & =\text { Tri Hita Karana } \text { culture } \\
{[} & =\text { error }
\end{array}
$$

The coefficient of multiple determination is a measure of the suitability (godness of fit) of the regression equation, which is a variation of the dependent variable that can be explained by the independent variable. When the adjusted $\mathrm{R}^{2}$ value is smaller, the ability of the independent variables to explain the variation of the dependent variable is more limited. If the score is close to one means that the independent variables provide almost all the information needed to predict variations in the dependent variable (Ghozali, 2016: 95).

F statistical test aims to determine the feasibility of multiple linear regression models as an analysis tool that tests the effect of independent variables on the dependent variable. The test was carried out using significance level $0.05(\alpha=5 \%)$. T test is used to test if each independent variable significantly influences the dependent variable. This test can be done by looking at the results of the regression conducted with the SPSS program, namely by comparing the significance level of each independent variable $0.05(\alpha=5 \%)$.

\section{RESULTS AND DISCUSSION}

Based on the profiles of 38 respondents who filled out the questionnaire in this study obtained the characteristics of research respondents. Characteristics of respondents are profile of the respondents who participated. The respondent's profile consists of gender, length of work at the relevant PAF, position, and education. The measurement is obtained through processing field data with the help of questionnaires that had been distributed, the details of the respondents can be seen in Table 2 .

Gender criteria of the respondent can be used as a reference to find out the proportion of male and female respondents. Based on Table 2 it can be seen that there are 18 respondents $(47.37 \%)$ and 20 female respondents $(53.63 \%)$. The length of work criteria can be used as a reference to find out how long the respondents have been an auditor at the relevant PAF. Based on Table 2 it can be seen that there are 36 people ( 94.74 percent) who have been working 1 to 5 years. There are 2 people $(5.26$ percent) who have been working 6 to 10 years. There is no respondent who works up to 20 years.

Criteria for the position of respondent can be used as a reference to determine the position of the respondent in this study. Based on Table 2. it can be seen that there are 12 senior auditors (31.58 percent), 
Table 2. Data Characteristics of Respondents

\begin{tabular}{|c|c|c|}
\hline \multirow[t]{2}{*}{ Characteristics of Respondents } & \multicolumn{2}{|c|}{ Number } \\
\hline & (Person) & Percentage $(\%)$ \\
\hline \multicolumn{3}{|l|}{ Gender } \\
\hline Male & 18 & 47.37 \\
\hline Female & 20 & 53.63 \\
\hline Total & 38 & 100 \\
\hline \multicolumn{3}{|l|}{ Length of work } \\
\hline $1-5$ years & 36 & 94.74 \\
\hline $6-10$ years & 2 & 5.26 \\
\hline$>10$ years & 0 & 0 \\
\hline Total & 38 & 100 \\
\hline \multicolumn{3}{|l|}{ Position } \\
\hline Partner & 0 & 0 \\
\hline Supervisor & 0 & 0 \\
\hline Manager & 0 & 0 \\
\hline Senior Auditor & 12 & 31.58 \\
\hline Junior Auditor & 26 & 68.42 \\
\hline Total & 38 & 100 \\
\hline \multicolumn{3}{|l|}{ Education } \\
\hline D3 & 4 & 10.53 \\
\hline S1 & 29 & 76.32 \\
\hline S2 & 5 & 13.16 \\
\hline S3 & 0 & 0 \\
\hline Total & 38 & 100 \\
\hline
\end{tabular}

Source: Data Processed, 2018

26 junior auditors (68.42 percent), while partner, supervisor and manager are not found in this study.

Criteria for the level of education of respondents can be used as a reference to find out the latest education of the respondents in this study. Based on Table 2. it can be seen that there are 4 participants with Diploma degree (10.53 percent), 29 respondents (76.32 percent) with Bachelor degree, 5 participants (13.16 percent) with Master degree, and there are no respondents with Doctoral degree.
This research has passed the validity and reliability test and the classical assumption test. The model feasibility test results show that the calculated $F$ value obtained is 17.397 with a significance value or p-value of 0.000 which is smaller than the value of $\alpha=0.05$, so it can be concluded that the variables of intellectual intelligence, emotional intelligence, spiritual intelligence, independence and Tri Hita Karana culture simultaneously have significant influence on auditor performance.

Table 3. Results of Multiple Linear Regression Analysis

\begin{tabular}{llrrrrr}
\hline & & \multicolumn{3}{c}{ Standardized } \\
Unstandardized Coefficients & \multicolumn{2}{c}{ Coefficients } & & \\
\cline { 3 - 5 } & & B & Std. Error & Beta & & S \\
\hline 1 & (Constant) & -8.461 & 3.688 & & -2.294 & 0.028 \\
& X1 & 0.322 & 0.145 & 0.247 & 2.222 & 0.033 \\
X2 & 0.207 & 0.087 & 0.239 & 2.376 & 0.024 \\
X3 & 0.426 & 0.165 & 0.268 & 2.589 & 0.014 \\
X4 & 0.319 & 0.145 & 0.223 & 2.196 & 0.035 \\
X5 & 0.318 & 0.108 & 0.299 & 2.933 & 0.006 \\
\hline
\end{tabular}

Source: Data Processed, 2018

From the results of the regression analysis in Table 3, the following equation can be made: $\mathrm{Y}=-8,461+0,322 \mathrm{X} 1+0,207 \mathrm{X} 2+0,426 \mathrm{X} 3+$ $0,319 \mathrm{X} 4+0.318 \times 5+\varepsilon$

First hypothesis $\left(\mathrm{H}_{1}\right)$ states that intellectual intelligence has a positive effect on auditor performance. The results show that $\mathrm{H}_{1}$ is accepted, that there is a positive influence between intellectual intelligence and auditor performance. The auditor's performance increases if he possesses higher the intellectual intelligence. Conversely, the performance will decrease if the auditor has lower intellectual intelligence. This research is in line with Fabiola (2005) 
stating that intellectual intelligence is a cognitive ability possessed by individuals to adapt effectively to complex and ever-changing environments that are influenced by genetics. The cognitive ability that is meant is someone's ability to understand and interpret every information he gets. It can be said that the higher the intellectual intelligence, the better the auditor's performance. This is in line with the theory put forward by Eysenck (1998).

Second hypothesis $\left(\mathrm{H}_{2}\right)$ shows that emotional intelligence has a positive effect on auditor performance. The results of the analysis state the second hypothesis (H2) can be accepted. The results showa positive influence between emotional intelligence and auditor performance. Auditor's performance will increase if he has higher emotional intelligence. Conversely, the performance decreases if he has lower emotional intelligence. Emotional intelligence is someone's ability to deal with frustration, the ability to control emotions, the spirit of optimism and the ability to establish relationships with others (Fabiola, 2005).

Third hypothesis $\left(\mathrm{H}_{3}\right)$ states that spiritual intelligence has a positive effect on auditor performance. The results show that the triple hypothesesare accepted, which means that the spiritual intelligence variable has a positive effect on auditor performance. The auditor performs better if he has higher spiritual intelligence.

Fourth hypothesis $\left(\mathrm{H}_{4}\right)$ states that independence has a positive effect on auditorperformance, so $\mathrm{H}_{4}$ is accepted. The results showed that independence influenced the auditor's performance. The independence of a public accountant is one of the very important characteristics of the public accountant in carrying out accounting checks on its clients. Independence is the main basis of public trust which is very important to assess the quality of audit services. Arumsari (2014) states that there is a relationship between auditor independence and auditor performance. An auditor with high independence will not be easily influenced and controlled by other parties in conducting the examinationand expressing his opinion, as result he will obtain better achievement. The results of this study are also consistent with research conducted by Trisnaningsih (2007) and Arifah (2012) which show that independence has a positive effect on auditor performance.

The fifth hypothesis $\left(\mathrm{H}_{5}\right)$ states that the culture of Tri Hita Karana influences auditor performance, therefore $\left(\mathrm{H}_{5}\right)$ can be accepted. The results showed an influence between the culture of Tri Hita Karana and auditor performance. Auditor's performance will increase if he applies Tri Hita Karana more. Applying Tri Hita Karana in working will lead the auditor to conduct quality audit. The results of this study are in line with research by Gunawan (2009), Dewi et al (2017) and Suparsabawa and Kustina (2018).

\section{CONCLUSION}

This research has been able to provide empirical evidence that intellectual intelligence, emotional intelligence, and spiritual intelligence have a positive effect on auditor performance. These three intelligences have a positive effect, which means that the level of intelligence of an auditor increases, the performance of an auditor increases. These three types of intelligence are important for an auditor in improving performance. The study also found that independence has a positive effect on auditor performance. Independence is a basic attitude that must be maintained by an auditor in improving performance. In addition, the culture of Tri Hita Karana has a positive effect on auditor performance as well. This implies the role of the Tri Hita Karana culture which contains universal noble values which is an important foundation applied for an auditor.

\section{REFERENCES}

Agus, D. (2003). Manajemen Supervisi: Petunjuk Praktis Bagi Para Supervisor. Jakarta: Raja Grafindo Persada.

Apriyanti. (2014). Pengaruh Kecerdasan Emosional, Kecerdasan Spiritual dan Perilaku Etis Terhadap Kinerja Auditor Pemerintah (Studi Empiris pada BPK-RI dan BPKP Perwakilan Provinsi Riau). Jurnal Ekonomi Universitas Riau Pekanbaru.

Arumsari, A. L. (2014). Pengaruh Profesionalisme Auditor, Independensi Auditor, Etika Profesi, Budaya Organisasi, dan Gaya Kepemimpinan terhadap Kinerja Auditor Eksternal (Studi Kasus pada BPK RI Perwakilan Provinsi Bali). EJournal Universitas Pendidikan Ganesha Jurusan Akuntansi Program S1.

Biberma, J, and Whittey, M. 1997.A Postmodern Spiritual Future For Work. Journal of Organizational Change Management, Vol. 10, No. 2, pp. 30-188

Chermiss, C. (1998). Working With Emotional Intelligence. The Consortium For Research On Emotional Intelligence in Organizations. New Jersey: Rugrets University. 
Choiriah, A. (2013). Pengaruh Kecerdasan Emosional, Kecerdasan Intelektual, Kecerdasan Spiritual, dan Etika Profesi Terhadap Kinerja Auditor Dalam Kantor Akuntan Publik. Jurnal Akuntansi.

Christiawan, Y. J. (2002). Kompetensi dan Independensi Akuntan Publik: Refleksi Hasil Penelitian Empiris. Jurnal Akuntansi Dan Keuangan, 4(2), 79-92.

Ciarrochi, J., Deane, F. P., \& Anderson, S. (2002). Emotional Intelligence Moderates the Relationship between Stress and Mental Health. Personality and Individual Differences. Personality and Individual Differences, 32(2), 197-209.

Dewi, P. N. K., Yuniarta, G. A., \& Julianto, P. (2017). Pengaruh Implementasi Budaya Tri Hita Karana, Efisiensi Night Auditor, Dan Kualitas Tenaga Kerja Terhadap Kinerja Hotel Berbintang Di Kabupaten Buleleng. E-Journal S1 Akuntansi Universitas Pendidikan Ganesha, 2(8).

Fernando, J., Mulki, J. P., \& Marshall, G. . (2005). A Meta-Analysis of The Relationship Between Organizational Commitment and Salesperson Job Performance. Journal of Business Research,58(1), 705-714.

Febiola Meirnayati. 2005. Analisis Pengaruh Kecerdasan Intelektual, Kecerdasan Emosi dan Kecerdasan Spiritual Terhadap Kinerja Karyawan. Tesis Program Pasca Sarjana Universitas Diponogoro, Semarang

Geiger, M. A., \& Rama, D. V. (2006). Audit Firm Size and Going Concern Reporting Accuracy. Accounting Horizons, 20(1), 1-17.

Ghozali, I. (2006). Aplikasi Analisis Multivariate Dengan Program SPSS. Cetakan Keempat. Semarang: Badan Penerbit Universitas Diponegoro.

Goleman, D. (2003). Emotional Intelligence. Journal of Business and Management. Jakarta: PT Gramedia Pustaka Utama.

Gunawan, K. (2009). Pengaruh Budaya Organisasi, Kepuasan Kerja dan Motivasi Kerja terhadap Gaya Kepemimpinan dan Kinerja Organisasi (Studi pada Lembaga Perkreditan Desa (LPD) di Bali). Jurnal Aplikasi Manajemen, 6(2), 441-449.

Hanafi, R. (2010). Spiritual Intelligence, Emotional Intelligence And Auditor's Performance. Jurnal Akuntansi Dan Auditing Indonesia, 14(1), 29-40.
Hofstede, G. (1983). The Cultural Relativity of Organizasional Practices and Theorities. Journal of International Studies, 14(2), 7589.

Hofstede, G. (1991). Culture and Organizations, Software of the Mind. New York: McGrawHill Education.

Hofstede, G., Neuijen, B., Ghayv, D. D., \& Sandes., G. (1990). Measuring Organization and Sosial Cultures: A Qualitatives Study a Cross Twenty Cases,. Administrative Sciane Quartely, 35(2), 286-316.

Idrus, M. (2002). Kecerdasan Spiritual Mahasiswa Yogyakarta, Psikologi Phronesis. Jurnal Ilmiah Dan Terapan, 4(2), 116-133.

Ikatan, A. I. (2002). Standar Profesional Akuntan Publik (SPAP). Jakarta: Salemba Empat.

Indriantoro, N. (2000). An Empirical Study of Locus of Control and Cultural Dimensions an Moderating Variable of The Effect Of Participative Budgeting on Job Performance And Satisfaction. Jurnal Ekonomi Dan Bisnis Indonesia, 15(1), 97-114.

Isabella. (2011). Pengaruh Kecerdasan Emosional, Kecerdasan Spiritual Dan Kecerdasan Intelektual Terhadap Kinerja Auditor Dalam Kantor Akuntan Publik. Katolik Soegijapranata Semarang.

Kalbers, L. P., \& Timothi, J. F. (1995). Pengaruh Current Ratio Dan Debt To Equity Ratio Terhadap Profitabilitas Dengan Intellectual Capital Sebagai Auditing/: A Journal of Practice \& Theory., 14(1), 64-86.

Maryani, T., \& U. Ludigdo. (2001). Survei Atas Faktor-faktor yang Mempengaruhi Sikap dan Perilaku Etis Akuntan. Jurnal Tema, 2(1), 4961.

Meirnayati, F. (2005). Analisis Pengaruh Kecerdasan Intelektual, Kecerdasan Emosi dan Kecerdasan Spiritual Terhadap Kinerja Karyawan. tesis. Universitas Diponogoro, Semarang.

Meyer, J. P., Gellatly, I. R., Paunonen, S., \& Goffin, R. (1989). Organizational Commitment and Job Performance: It's the Nature of the Commitment That Counts. Journal of Applied Psychology, 74(1), 152-156.

Mitroff, L. ., \& Denton, E, A. (1999). A Study of Spiritualty in The Work Place. Sloan Management Review, 40(4), 83-92.

Mowday, R. T., Porter, L. W., \& Steers, R. M. (1992). Employee-Rganization Linkages: The 
Psychology Of Commitment, Absenteeism, And Turnover. New York: Academic Press.

Nouri, H., \& Parker, R. J. (1996). The Effect of Organization Commitment on The Relation Betwen Budgetary Participation an Budgetary Slack. Behavioral Research in Acounting, 8(1), 76-90.

Novia, M. T., \& Ariyanto, D. (2016). Profesionalisme Sebagai Pemoderasi Pengaruh Independensi pada Kinerja Auditor. E-Jurnal Akuntansi, 14(3), 1895-1923.

Pande, P. M. (2012). Pengaruh Kecerdasan Intelektual, Kecerdasan Emosional, Dan Kecerdasan Spiritual Pada Kinerja Alumni Fakultas Ekonomi Universitas Udayana (Studi Empiris Mahasiswa MAKSI dan PPak). EJurnal Akuntansi, 1(1), 1-17. https://doi.org/ 10.24843/jiab.2019.v14.i01.p12

Robbins, S. P., \& Judge, T. A. (2008). Perilaku Organisasi Edisi ke-12. Jakarta: Salemba Empat.

Saputra, K. A. K. (2012). Pengaruh Lokus Of Kontrol Terhadap Kinerja Dan Kepuasan Kerja Auditor Dengan Kultur Lokal Tri Hita Karana Sebagai Variabel Moderasi. Jurnal Akuntansi Multiparadigma, 3(1), 86-100.

Sugiyono. (2016). Metode Penelitian Bisnis (Pendekatan Kuantitatif, Kualitatif, dan $R \& D)$. Bandung: Alfabeta.

Suparsabawa, I. N. R., \& Kustina, K. T. (2018). Pengaruh Penerapan Good Corporate
Governance Dan Budaya Tri Hita Karana Terhadap Kinerja Manajerial Lembaga Perkreditan Desa (LPD). Jurnal Riset Akuntansi (JUARA), 8(1), 58-68.

Triandis, H. C. (1980). Values, Attitudes and Interpersonal Behavior. Lincoln: University of Nebraska Press.

Trinaningsih, S. (2007). Independensi Auditor Dan Komitmen Organisasi Sebagai Mediasi Pengaruh Pemahaman Good Governance, Gaya Kepemimpinan Dan Budaya Organisasi Terhadap Kinerja. In Prosiding Simposium Nasional Akuntansi (Vol. 10, pp. 1-56).

Wiersma, M. L. (2002). The Influence of Spiritual "Meaning-Making" On Career Behaviour. Journal of Management Development, 21(7), 497-520.

Wijana, D. G. A., \& Ramantha, I. W. (2015). Integritas Sebagai Pemoderasi Pengaruh Komitmen Organisasi Pada Kinerja Auditor. EJurnal Akuntansi, 10(3), 841-851.

Wijayanti, G. L. (2012). Peran Kecerdasan Emosional Dan Kecerdasan Spiritual Dalam Meningkatkan Kinerja Auditor. Jurnal Ilmiah Mahasiswa Akuntansi, 11(1).

Yuliana, G. S., \& Latrini, Y. (2016). Pengaruh Kecerdasan Emosional, Kecerdasan Spiritual, Kecerdasan Intelektual dan Independensi pada Kinerja Auditor. E-Jurnal Akuntansi, 16(2), 1034-1062. 